Volume 9, No.1, January - February 2020

International Journal of Advanced Trends in Computer Science and Engineering

Available Online at http://www.warse.org/IJATCSE/static/pdf/file/ijatcse126912020.pdf

https://doi.org/10.30534/ijatcse/2020/126912020

\title{
A Review of Shape Variations and Test Angles for Crash Box Application
}

\author{
Jeffery Jep Brown ${ }^{1}$, Al Emran Ismail ${ }^{2}$ \\ Faculty of Mechanical and Manufacturing Engineering, University Tun Hussein Onn Malaysia, Malaysia, \\ 1jejep007@gmail.com, ${ }^{2}$ emran@uthm.edu.my.com / al_emran@ @otmail.com
}

\begin{abstract}
A thin-walled structure has been adopted in various applications. One of them is being used as a crash box for automotive industries. Due to the fact that thin-walled structures are now an integral part of the safety system, the crashworthiness characteristics of this structure has to be studied to find out how much energy absorption can be performed. Besides energy absorption, specific energy absorption also has to be taken into consideration. In the light of new and updated technology, crush test can now be done in simulations. This means that more possible catastrophic accidents can be simulated and gives access to enhance the crashworthiness of the crash box. Apart from that, crashworthiness also depends so much on the geometries of the tubes. Some bio-inspired and origami novel design proposed by previous studies can significantly improve the energy absorption ability.
\end{abstract}

Keywords: Thin-walled structures, energy absorption, specific energy absorption, axial and oblique crash test, novel design

\section{INTRODUCTION}

Highlight a section that you want to designate with a certain style, then select the appropriate name on the style menu. Lightweight thin-walled structures have inspired applications for a lot of industrial sectors. For instances, aerospace and automobile. Thin-walled tubes are often adapted in industries like automobiles as a safety feature to absorb energy from a frontal collision in which will minimize the damages and potential injuries of the passenger. This is due to the fact that they offer numerous advantages like cheaper to manufacture, not heavy and have good energy absorption efficiency. The bending collapse mechanism for thin-walled structures begun studied since the 1980s. These structures are lightweight, great energy-absorbing ability and low-cost manufacturability. Thus, qualify them to be adapted in structures where safety is a priority. The characteristics of energy absorption is an important deformation mode. That is why it received wide attention. A lot of works has been done in this field so far.

\subsection{Factors Affecting Crushing Performance}

Nowadays, the research in the energy absorption field gained popularity amongst scientists and researchers in the hope of improving the energy absorption performance and developing effective designs cross-sectional shapes with high energy absorption capacity. Apart from cross-sectional geometries, the material also has to be taken into consideration. The cost and crash performance indicator are also vital.[1] This is because each material has different mechanical properties. On the other hand, the crash box has to be tested in a bigger perspective. This is to simulate the best crash possible by using multiple angles subjected to the models. In real life crash or accidents, the odds for the crash to be $100 \%$ axial is very low.

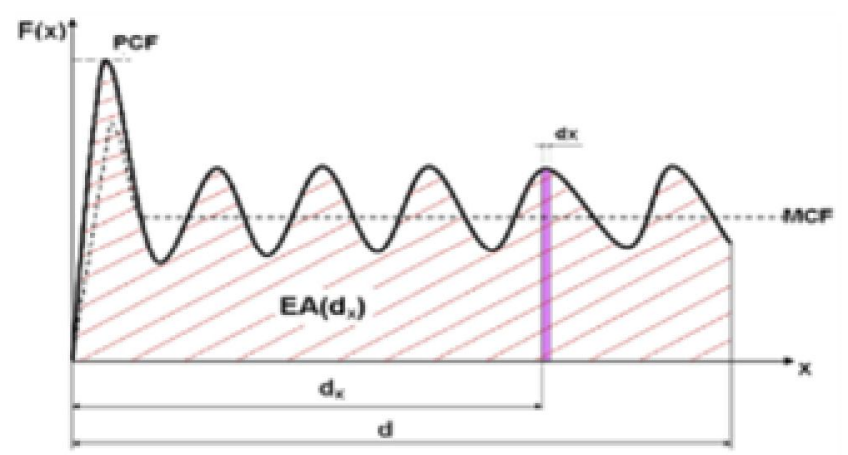

Figure 1: Force-displacement curve under impact loading.

\section{THIN-WALLED STRUCTURES AS CRASH BOX}

Use either SI (MKS) or CGS as primary units. (SI units are strongly encouraged.) English units may be used as secondary. The urbanization demands are the prior cause for the growing number of vehicles today. That fact leads to the inevitable rising number of vehicles. Accidents or crashes cannot be avoided due to the increment of the number of vehicles in this age of the internet of things. So, making the passengers of the vehicle as safe as possible should be made first in the priority list, because accidents cannot be avoided. This is where the crash box comes to play. Crash box show some performance limitation when it is under axial crushing process. For instance, unstable deformation mode as well as high initial peak force. On the other hand, when under an oblique load, energy absorption prone to reduce due to yield global buckling. 


\subsection{Hollow tubes.}

The key objective of this research is to identify the best available cross-sectional configuration and design and present different existing models for energy absorption capability. Hence, for this section, a review of the energy absorption performance in accordance with shapes and geometries will be discussed. Over the years, hollow tubes have been very popular to be used as a crash box. This is because of their light-weight characteristics. Not only that, they are able to perform as a crash box in the automotive industries.

In their paper, Abbasi et. al[2]. Came up with the 12-edge configuration because of the intention of distributing more materials closer to the corners in the geometry. Design objectives were always related to the wall thickness. In an example, a thicker wall always resulted in higher crushing force efficiency as well as specific energy absorption. Sadighi et. al.[5] said the results of a simple aluminium structure with no corrugations should be considered if the study of a variation of corrugated structures is ought to be done.

Nan et. al.[6], simple shapes such as cylinders can be estimated in terms of elastic-plastic buckling. Other than that, simple loading and boundary conditions are also can be predicted via analytical approach. Furthermore, there was some disadvantage to the analytical approach. This approach had to cast away the large assumptions and simplification because of the inconsistency compared to the experimental approach. The truth is, complicated friction and actual forming condition cannot be considered in the analytical approach.

Aluminium tube collapse in irregular diamond shape mode as the angle of impact increases. CFRP collapse in splaying, tearing, socking, micro-fragmenting and catastrophic mode. Energy absorption at 0-10 shows marginal difference but at 10, CFRP experiences major drop while aluminium drop steadily.[7] The proposed models are square, cylinder, hexagon and decagon. The result was with the help of triggers, deformation pattern and energy absorption changed significantly compared to that with no triggers. The results varied in accordance with each geometry, but hexagon absorbed energy the most. Meanwhile, without trigger, the cylinder had the highest energy absorption.[8]

Hussein et. al. said that with the help of triggers, energy absorption, as well as deformation pattern, changed significantly compared to that with no triggers. The results varied in accordance with each geometry, but hexagon absorbed energy the most. Meanwhile, without trigger, the cylinder had the highest energy absorption. The proposed models are square, cylinder, hexagon and decagon. Those models were simulated with an axial crush test using Hyper Mesh.

\subsection{Foam-filled Crash box}

Li et.al.[9] mentioned that the initial crushing force of square tube under axial crush can be reduced substantially with the help of initiators like a set of grooves. This also causes higher
CFE, altered the mode of deformation and energy absorption capacity. It is shown that the ellipse tube foam-filled performed the best in term of overall specific energy absorption. Besides, under multiple loading crush angles, the foam-filled tubes shown better performance compared to the hollow tubes.[10]

\subsection{Multi-cell and Multi-tubular Crash box}

Surface gradient-Compared with a single cell tube, a traditional multi-cell tube deformed into a desirable concertina crushing mode, with a short folding wave as well as counted and uniform lobes, which was beneficial for stable and efficient energy absorption.

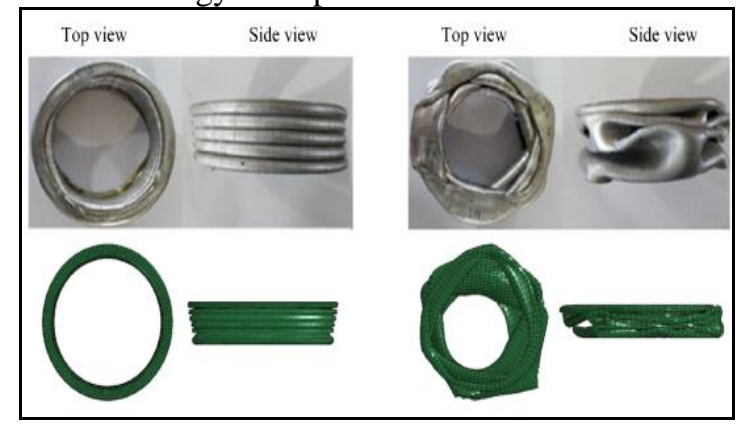

(a)

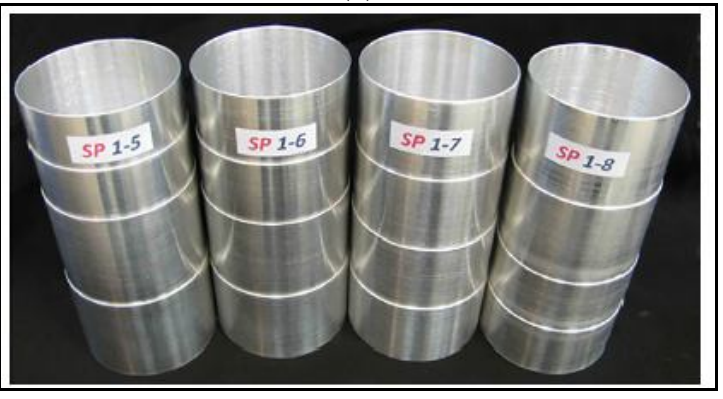

(b)

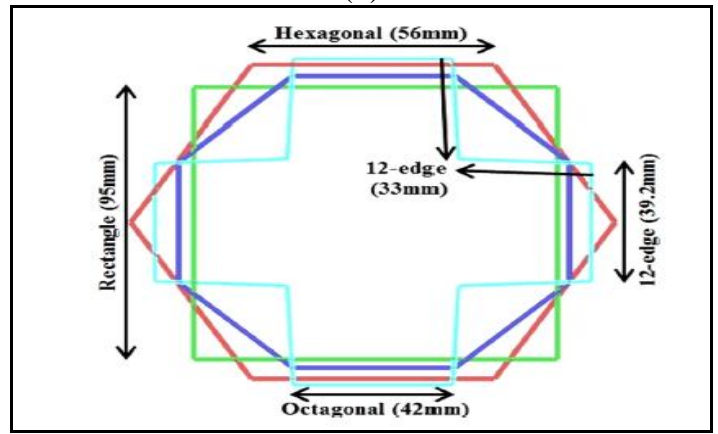

(c)

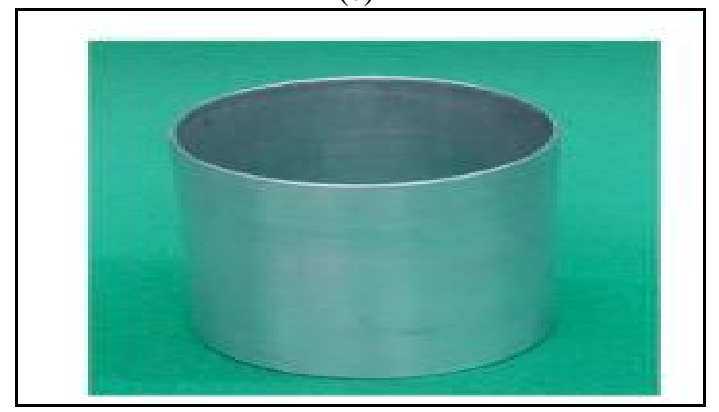

(d)

Figure 2: Hollow tubes as crash box (a)[3], (b)[4], (c)[2], (d)[5] 
In addition, a simulation analysis was carried out as described in Section 3 to show that with the increase of cell density, the response curve evolved more stably. Additionally, the energy-absorbing efficiency had a great improvement from a single cell to the $5 \times 5$ cells. With the increase of cell density, the improved behaviour gradually slowed down and eventually hit a bottleneck. Combining the multi-cell structure with the DSG amplified the mean load ratio and further improved the load capacity.[11]

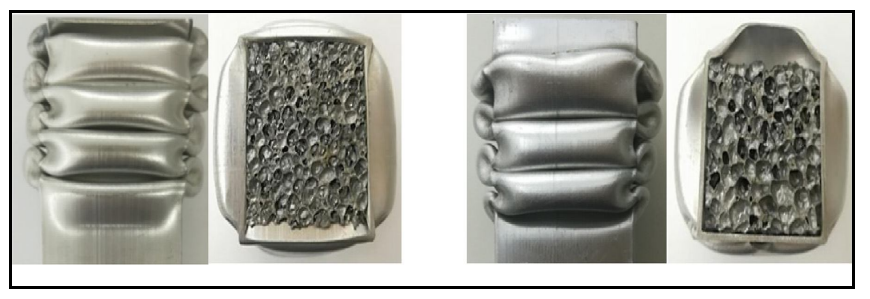

Figure 3: Foam-filled model



(a)

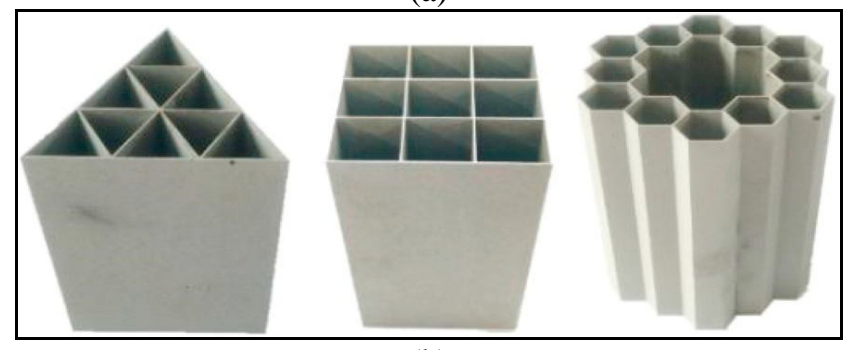

(b)



Figure 4: Multi-cellular model (a)[11], (b)[13][12] and (c)[12][12][12](Luo \& Fan, 2018)[12](Luo \& Fan, 2018)

Impacting mechanical performance can be enhanced effectively with a side fractal design. Designed to have the same mass, hexagonal side fractal structures gave the best performance compared to the triangle and square ones. Fractal factor and thickness of the wall can significantly affect the structure's mean crushing force. Increment of both will enhance the MCF. In the other hand, too much increment would alter the folding mode to large wavelength folding mode from the progressive mode. This hugely decreasing the crashworthiness of the crash box.[13].
A sandwich-walled tube was a better energy absorber compared to a thin-walled structure with exact mass. Mean crushing force for the sandwich-walled tube was better in 2.5 times more than the simple thin-walled tube. [12] Vineyagar et. al. Bi-tubular tubes had higher average force compared to the single tube structures. Energy absorption also increased by $132 \%$. Furthermore, a noticeable increment of energy absorption efficiency by $213 \%$. Overall, the bi-tubular tube with hexagon inner tube had the highest SEA of all.[19] Increasing number of tubes by $1,2,3,4,5$ results in specific energy absorption (SEA) increases by $37 \%, 66 \%, 105 \%, 88 \%$ respectively. Meanwhile, crush force efficiency (CFE) increased by $62 \%, 96 \%, 154 \%, 185 \%$ respectively. Thus, an increasing number of tubes can increase the SEA and CFE.[23]

\subsection{Hybrid Crash Box}

Use one space after periods and colons. Hyphenate complex modifiers: "zero-field-cooled magnetization." Avoid dangling participles, such as, "Using (1), the potential was calculated." [It is not clear who or what used (1).] Write instead, "The potential was calculated by using (1)," or "Using (1), we calculated the potential." The CFRP with ply orientation influenced the ability to absorb energy with the orientation of $\left[0^{\circ} / 90^{\circ} / 0^{\circ} / 90^{\circ}\right]$. This had improved 35\% of EA in comparison to the one with $\left[90^{\circ} / 0^{\circ} / 90^{\circ} / 0^{\circ}\right]$. The deformation of the metallic and hybrid structure was influenced by the number of cells. It is noticed that the energy-absorbing ability was significantly enhanced by increasing the number of cells. The hybrid multi-cell structures configuration could be a novel one.[14].

The conventional aluminium tube is a good energy absorber, but it can be quite heavy and expensive. Thus, the search for new material rose to popularity. The effect of carbon fibre reinforced polymer is investigated. The ability to absorb the energy performance of the structures was affected by the aspect ratios in structures. A fully progressive mode of buckling deformation can be seen from a low aspect ratio lattice structure. On the contrary, the ones with high aspect ratio shown to be in both progressive and global buckling modes.[15] Ismail deduced that energy absorption is proportionate to the number of layer[17].

The varying wall thickness of hybrid aluminium tube had a minor effect on the mode of deformation as well as specific energy absorption. By making the number of layers increased, $\left(+45^{\circ} /-45^{\circ}\right)$ it will lead to the generation of the transverse mode of bending for the tubes. Under $20^{\circ}$ and $30^{\circ}$ angle of impact, resulting in a major reduction by $20.8 \%$ for specific energy absorption.[16] Besides, Kahlid et. al.[18] mentioned that the energy absorption ability was affected greatly by the fibre orientation. Jahromi \& Hatami said the cell size with the angle $0^{\circ}$ collapsed symmetrically. It was also concluded that the increased cell size would decrease the peak force. Thus, more energy is absorbed. Increased thickness \& multilayered shown significant changes in the initial maximum crushing force. Crushing efficiency was improved.[20]. 
Ying et. al. did a study on the tapering effect on crashworthiness of the crash box. The square metal structure with fibre-reinforced tapering was made varied in tapering orientation to study the effect of tapering. The tapering orientation: $0^{\circ}, 2.5^{\circ}, 5^{\circ}, 7.5^{\circ} 10^{\circ}, 15^{\circ}$. Crush test were done in simulation and experiment under axial loading. The tapered model with $0^{\circ}$ orientation had maximum force. With the increasing angle of tapering, the force exerted changes linearly. The force depends on tapering orientation and thickness. Tapering may affect collapse pattern and energy-absorbing ability. The presented method may be set as a benchmark for simulation and experimental results.[18]

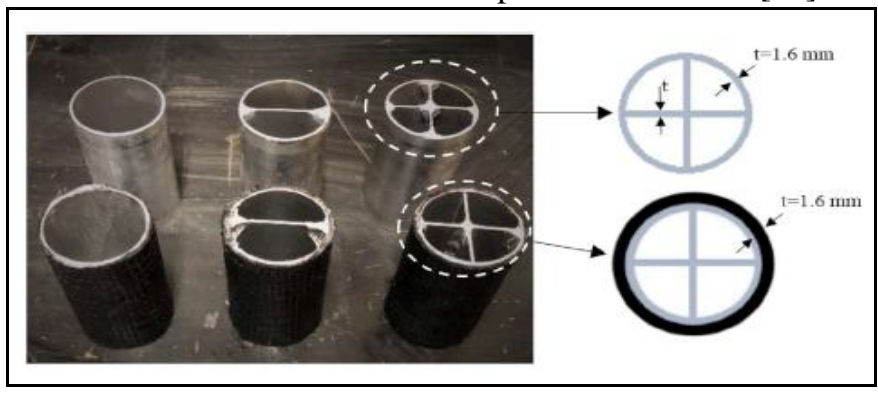

(a)

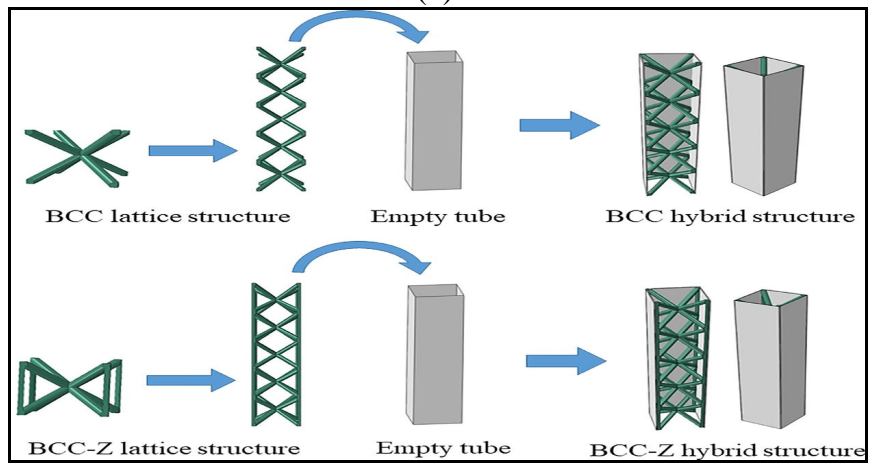

(b)



(c)

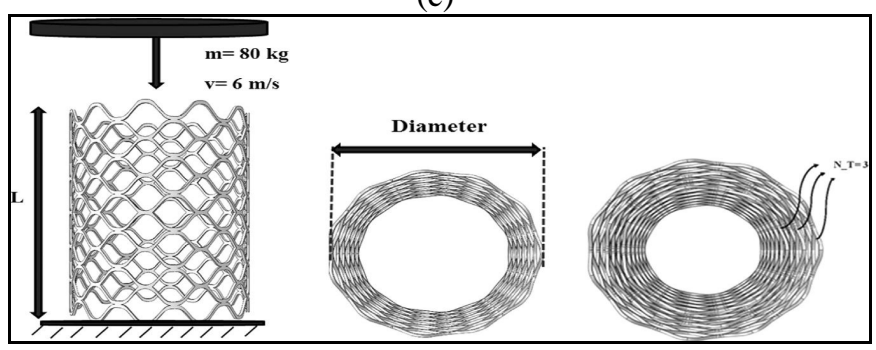

(d)

Figure 5: Hybrid models of crash box (a)[14], (b)[15], (c)[16], (d)
The table above explained that the past researcher has mentioned that varying the geometry and material of the crash box is not only affects the energy absorption ability but also changed the collapsing model of the tested models. In the table, above also mentioned the shape variation such as round, rectangle, square, hexagon, pentagon, octagon, tapered, multi-cell, and foam-filled as well. It was discovered that different geometries have different crashworthiness characteristics. a significant effect on crashworthiness is due to the shape of the multi-cell structure.[26]

Table 1: Summary of previous researches on thin-walled structures as a crash box.

\begin{tabular}{|l|l|}
\hline \multicolumn{1}{|c|}{ Authors } & \multicolumn{1}{|c|}{ Contribution } \\
\hline (2018)[7] & $\begin{array}{l}\text { Aluminium tube collapse in irregular } \\
\text { diamond shape mode as the angle of } \\
\text { impact increases. CFRP collapse in } \\
\text { splaying, tearing, socking, } \\
\text { micro-fragmenting and catastrophic } \\
\text { mode. Energy absorption at 0-10 shows } \\
\text { marginal difference but at 10, CFRP } \\
\text { experiences major drop while aluminium } \\
\text { drop steadily. }\end{array}$ \\
\hline $\begin{array}{l}\text { Hussain et. al. } \\
\text { (2017)[19] }\end{array}$ & $\begin{array}{l}\text { With the help of triggers, } \\
\text { crashworthiness changed significantly } \\
\text { compared to that with no triggers. The } \\
\text { results varied in accordance with each } \\
\text { geometry, but hexagon absorbed energy } \\
\text { the most. Meanwhile, without trigger, } \\
\text { the cylinder had the highest energy } \\
\text { absorption. }\end{array}$ \\
\hline $\begin{array}{l}\text { Ying et. al. } \\
\text { (2016)[20] }\end{array}$ & $\begin{array}{l}\text { The proposed model with 0 orientation } \\
\text { had maximum force. With the increasing } \\
\text { angle of tapering, the force exerted } \\
\text { changes linearly. The force depends on } \\
\text { tapering orientation and thickness. } \\
\text { Tapering may affect collapse pattern and } \\
\text { energy-absorbing ability. The presented } \\
\text { method may be set as a benchmark for } \\
\text { simulation and experimental results. }\end{array}$ \\
\hline Wahromi \& & $\begin{array}{l}\text { Bi-tubular tubes had higher average } \\
\text { force compared to the single tube } \\
\text { structures. Energy absorption also } \\
\text { increased by 132\%. Furthermore, a } \\
\text { noticeable increment of energy } \\
\text { absorption efficiency by 213\%. Overall, } \\
\text { abi-tubular tube with hexagon inner tube } \\
\text { had the highest SEA of all }\end{array}$ \\
(2017)[22] & $\begin{array}{l}\text { The cell size with angle 0 collapsed } \\
\text { symmetrically. It was also concluded that } \\
\text { theincreased cell size would decrease the } \\
\text { peak force. Thus, more energy is } \\
\text { absorbed. Increased thickness \& } \\
\text { multilayered shown significant changes } \\
\text { in the initial maximum crushing force. } \\
\text { Crushing efficiency was improved. }\end{array}$ \\
The finayagar \& \\
Kumar \\
(2017)[21]
\end{tabular}




\begin{tabular}{|l|l|}
\hline (2018)[23] & $\begin{array}{l}\text { half-wavelength. This is due to the } \\
\text { presence of the cells in the models. it was } \\
\text { found that more cells would cause lower } \\
\text { half-wavelength. This phenomenon } \\
\text { brought great improvement in the } \\
\text { energy-absorbing ability. Thus, the } \\
\text { increasing number of cells the structure } \\
\text { had, the better its crashworthiness. }\end{array}$ \\
\hline $\begin{array}{l}\text { Baroutaji et.al } \\
(2015)[24]\end{array}$ & $\begin{array}{l}\text { Specific energy absorption increases as } \\
\text { thickness increases and diameter } \\
\text { decreases. Crush force became greater in } \\
\text { a smaller diameter. Thin and short tubes } \\
\text { less influenced by changing the tube } \\
\text { diameter. Optimum design is said to } \\
\text { have a smaller width and thicker } \\
\text { diameter. }\end{array}$ \\
\hline $\begin{array}{l}\text { Abbasi et.al. } \\
(2015)[2]\end{array}$ & $\begin{array}{l}\text { Concluded that octagon structure with } \\
12 \text { edges section shown the greatest } \\
\text { ability to absorb energy in term of } \\
\text { specific energy and crushing force } \\
\text { efficiency. }\end{array}$ \\
\hline $\begin{array}{l}\text { Nia \& } \\
\text { Chahardoli } \\
\text { (2016)[25] }\end{array}$ & $\begin{array}{l}\text { Increasing number of tubes by 1, 2, 3, 4, } \\
\text { (SEA) increases by 37\%, 66\%, 105\%, } \\
88 \% \text { respectively. Meanwhile, crush } \\
\text { force efficiency (CFE) increased by 62\%, } \\
96 \%, 154 \%, 185 \% \text { respectively. Thus, an } \\
\text { increasing number of tubes can increase } \\
\text { the SEA and CFE. }\end{array}$ \\
\hline $\begin{array}{l}\text { Greatest energy absorption= hybrid } \\
\text { tubes: SEA decreased by 10\% only as the } \\
\text { angle increase and CFRP tube decreased } \\
\text { by 20.6\% }\end{array}$ \\
\hline 2018)[16]
\end{tabular}

Besides, the type of materials also being studied to further the understanding of crashworthiness. There were several materials has been studied to be used for thin-walled structures. For instance, aluminium, carbon fibre-reinforced polymer and hybrid. On the other hand, the impact loading test was not only carried out axially. Oblique impact test also being performed as in real life crash, it is more likely to happen rather than pure axial crash. The weighting factors selection for different load angles would have an effect on the optimal solutions to SEA[27]. So, to know and detect the threshold crush angle is vital for the transition. [28] Thus, by varying the angle of impact, the crashworthiness characteristic of the studied thin-walled structures can be analyzed deeper. At the same time, the collapsing model is also important in order to characterize the crashworthiness. Progressive folding is the desired mode of deformation.[29]

\section{NOVEL DESIGN PATTERN}

In this section, the novel crash box design will be discussed. The novel designs proposed by these researchers spark a new generation of crash box. Those new designs are often bio-inspired and origami oriented. The reasons are to get the crash box to have better-collapsing modes which will surely improve their crashworthiness and energy-absorbing ability.

The proposed kirigami novel pattern was meant to induce folding with the targeted energy absorption ability. Within a wide range of cross-sectional tubes, kirigami crash box was able to induce the extensional mode. This is of course under quasi-static axial crushing and the mean crushing force for typical kirigami crash box increases by $33.9 \%$.[31]

For the novel bionic multi-cell structure, traditional multi-cell tubes were infused with it. Cylindrical tubes were put at the intersections of the panels. The study revealed novel design was better at absorbing energy than the traditional multi-cell structure. Not only that, the specific energy absorption of the bionic structure also exceeds the traditional ones too, with the same number of panels. This proved that the novel design is better at absorbing energy than the traditional multi-cell tubes.[32]

In the edge of $4^{\text {th }}$ industrial revolution, the implementation of these elements is crucial for an example in optimizing the geometrical shapes so that it can be absorbed higher crash energy during vehicular collisions [36-38].

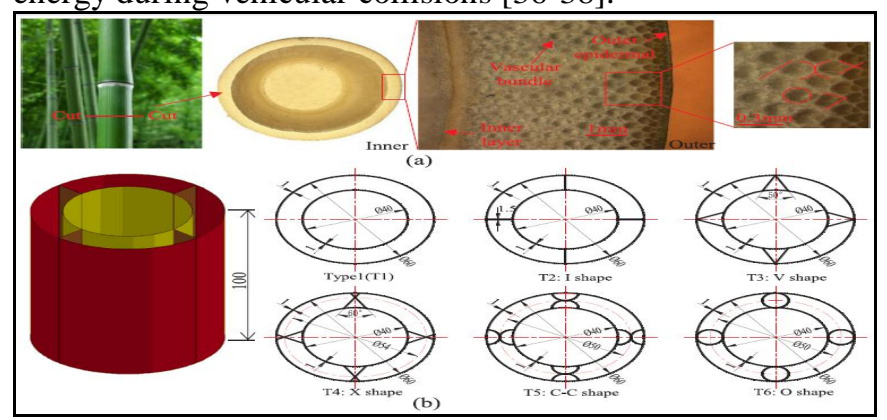

(a)

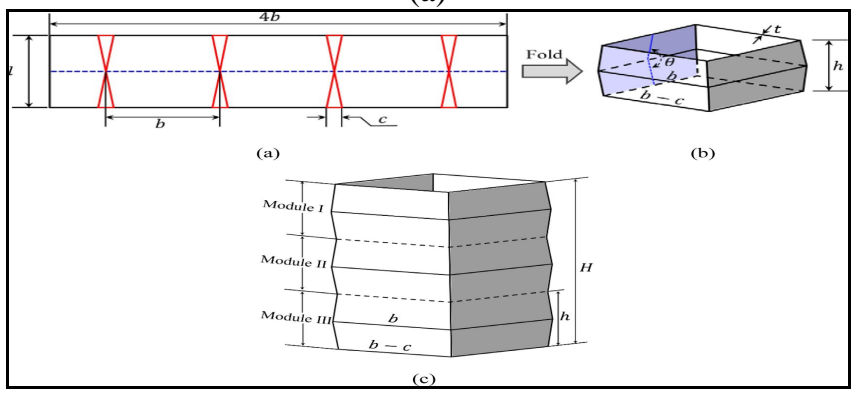

(b)

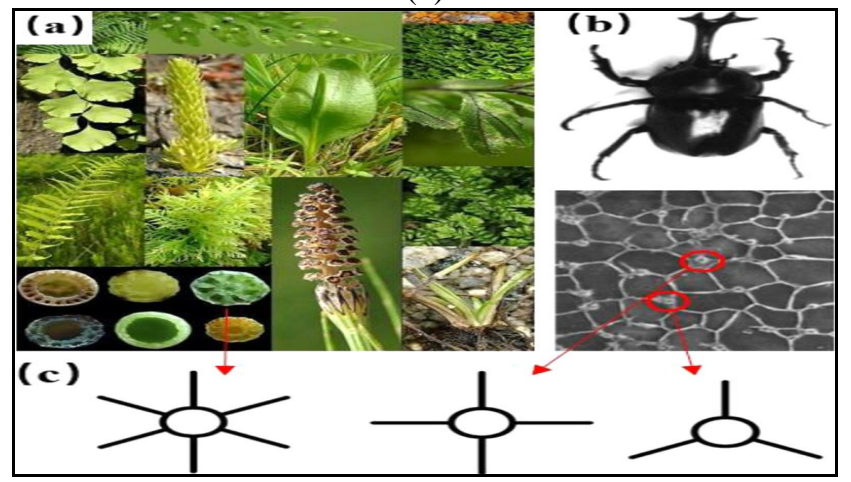

(c)

Figure 6 : Novel bio-inspired and origami crash box (a)[30], (b)[31], (c)[32] 
Table 2: Previous research on the novel design of thin-walled structures.

\begin{tabular}{|c|c|c|}
\hline Author & Novel Design & $\begin{array}{l}\text { Crashworthiness } \\
\text { Performance }\end{array}$ \\
\hline $\begin{array}{l}\text { Ma et.al. } \\
(2014)[33]\end{array}$ & $\begin{array}{l}\text { A pre-folded } \\
\text { kite-shaped rigid } \\
\text { origami pattern }\end{array}$ & $\begin{array}{l}\text { Novel design induced } \\
\text { rigid complying mode } \\
\text { as well as non-rigid } \\
\text { complying mode. } \\
29.2 \% \text { increment for } \\
\text { specific energy } \\
\text { absorption. The } \\
\text { theoretical study } \\
\text { matches with numerical } \\
\text { results. }\end{array}$ \\
\hline $\begin{array}{l}\text { Gao et.al } \\
(2016)[10]\end{array}$ & $\begin{array}{l}\text { Foam-filled } \\
\text { double ellipse } \\
\text { tube }\end{array}$ & $\begin{array}{l}\text { The double ellipse tube } \\
\text { was better at absorbing } \\
\text { energy compared to the } \\
\text { other model. }\end{array}$ \\
\hline $\begin{array}{ll}\text { Ha } & \text { et.al } \\
(2018) & {[34]}\end{array}$ & $\begin{array}{l}\text { Tubular } \\
\text { corrugated } \\
\text { configuration } \\
\text { tube (CCT) } \\
\text { mimicking the } \\
\text { coconut tree } \\
\text { profile. }\end{array}$ & $\begin{array}{l}\text { The crashworthiness } \\
\text { was mostly affected by } \\
\text { the tapering angles. } \\
\text { Smaller tapering angle } \\
\text { gave better specific } \\
\text { energy absorption CCT } \\
\text { can reduce up to } 64.4 \% \\
\text { and } 81.5 \% \text { undulation } \\
\text { of load-carry capacity } \\
\text { (ULC). }\end{array}$ \\
\hline $\begin{array}{l}\text { Ming et,al } \\
(2019)[31]\end{array}$ & $\begin{array}{l}\text { Kirigami crash } \\
\text { box }(\mathrm{KCB})\end{array}$ & $\begin{array}{l}\text { The KCB can induce } \\
\text { collapse mode that } \\
\text { could initiate collapsing } \\
\text { in extensional mode. } \\
\text { The geometric } \\
\text { imperfection can reduce } \\
\text { initial peak force by } \\
39 \% \text {. }\end{array}$ \\
\hline $\begin{array}{l}\text { Cetin et.al. } \\
(2019)[15]\end{array}$ & $\begin{array}{l}\text { Hybrid design } \\
\text { (thin-walled } \\
\text { structure filled } \\
\text { with periodic } \\
\text { lattice } \\
\text { materials). }\end{array}$ & $\begin{array}{l}\text { Hybrid structures } \\
\text { absorbed twice as much } \\
\text { as individual structures. } \\
\text { Its low aspect ratio } \\
\text { shows fully progressive } \\
\text { buckling. Meanwhile, } \\
\text { the high aspect ratio } \\
\text { shows both progressive } \\
\text { and global buckling } \\
\text { modes. }\end{array}$ \\
\hline $\begin{array}{l}\text { Jiang et.al. } \\
(2019)[32]\end{array}$ & $\begin{array}{l}\text { Bio-inspired } \\
\text { constituent } \\
\text { element (BCE) } \\
\text { which is a } \\
\text { hollow } \\
\text { cylindrical tube } \\
\text { with various } \\
\text { numbers of } \\
\text { panels. } \\
\end{array}$ & $\begin{array}{l}\text { Higher SEA than } \\
\text { traditional angle. The } \\
\text { formula used to predict } \\
\text { the results agreed with } \\
\text { the experiment by } 10 \% \\
\text { error. }\end{array}$ \\
\hline $\begin{array}{l}\text { Wang et.al. } \\
(2019)[35]\end{array}$ & $\begin{array}{l}\text { Origami-inspire } \\
\mathrm{d} \quad \text { multi-cell }\end{array}$ & \begin{tabular}{llr}
\multicolumn{2}{l}{ Optimization result } \\
showed that the
\end{tabular} \\
\hline
\end{tabular}

\begin{tabular}{|l|l|l|}
\hline & $\begin{array}{l}\text { thin-walled } \\
\text { structure for the } \\
\text { high-speed train. }\end{array}$ & $\begin{array}{l}\text { thin-walled structure } \\
\text { with angle twist of 3.24, } \\
\text { the height of 30mm and } \\
\text { thickness of 4mm, the } \\
\text { initial peak crushing } \\
\text { force had 29.36\% } \\
\text { reduction. Meanwhile, } \\
\text { energy absorption is } \\
\text { 269.90kJ. }\end{array}$ \\
\hline $\begin{array}{l}\text { Khanchehza } \\
\text { (2016) }\end{array}$ & $\begin{array}{l}\text { Thin-walled } \\
\text { square section } \\
\text { with novel } \\
\text { patterns of } \\
\text { internal blades } \\
\text { as stiffeners. }\end{array}$ & $\begin{array}{l}\text { The presence of the } \\
\text { novel blades improved } \\
\text { energy absorption by } \\
199 \% . \text { While specific } \\
\text { energy absorption } \\
\text { increased by 92\%. It } \\
\text { was concluded that two } \\
\text { parallel vertical blades } \\
\text { have the best } \\
\text { crashworthiness. }\end{array}$ \\
\hline
\end{tabular}

\section{CONCLUSION}

Thin-walled structure application has expanded in the era of globalization. These structures had shown the potential to be used as a safety feature in cars and even high-speed trains. Apparently, the performance of these structures is measured in terms of their energy-absorbing ability, their collapsing mechanism and the amount of force can be exerted. Thus, to get better performance, there are few aspects can be modified, enhanced, eliminated or even changed. Those parameters include geometry and material. For examples, there are polygons, multi-cellular models, bio-inspired and origami types. Not only have that, the material of the crash boxed also important. Material like CFRP and aluminium respectively shown significant differences when it comes to crashworthiness characteristics. So, in a nutshell, crash box's ability to absorb energy depends a lot on the geometry, material and collapsing modes.

\section{ACKNOWLEDGEMENT}

Authors acknowledge the financial support to Research Fund E15501, Research Management Centre, Universiti Tun Hussein Onn Malaysia.

\section{REFERENCES}

[1] B. Wang and C. Zhou, The imperfection-sensitivity of origami crash boxes, Int. J. Mech. Sci., vol. 121, pp. 58-66, 2017.

[2] M. Abbasi, S. Reddy, A. Ghafari-nazari, and M. Fard, Multiobjective crashworthiness optimization of multi-cornered thin-walled sheet metal members, Thin-Walled Struct., vol. 89, pp. 31-41, 2015.

[3] F. Xu, X. Zhang, and $\mathrm{H}$. Zhang, A review on functionally graded structures and materials for energy absorption, Eng. Struct., vol. 171, pp. 309-325, 2018. 
[4] M. Abolfathi and A. A. Nia, Optimization of energy absorption properties of thin-walled tubes with combined deformation of folding and circumferential expansion under axial load, Thin-Walled Struct., vol. 130, pp. 57-70, 2018.

[5] A. Sadighi, A. Eyvazian, M. Asgari, and A. Magid, A novel axially half corrugated thin-walled tube for energy absorption under Axial loading, Thin-Walled Struct., vol. 145, p. 106418, 2019.

[6] L. Nan, Y. He, L. Heng, and Y. Siliang, Plastic wrinkling prediction in the thin-walled part forming process : A review, Chinese J. Aeronaut., vol. 29, no. 1, pp. 1-14, 2016.

[7] G. Sun, S. Li, G. Li, and Q. Li, On crashing behaviors of aluminium / CFRP tubes subjected to axial and oblique loading : An experimental study, Compos. Part B, vol. 145, pp. 47-56, 2018.

[8] N. Hussain, S. Regalla, Y. R.-P. Engineering, and undefined 2017, Comparative Study of Trigger Configuration for Enhancement of Crashworthiness of Automobile Crash Box Subjected to Axial Impact Loading, Procedia Engineering, Vol. 173, pp. 1390-1398, 2017.

[9] Z. Li, S. Rakheja, and W. Shangguan, Study on crushing behaviors of foam- fi lled thin-walled square tubes with di ff erent types and number of initiators under multiple angle loads, Thin-Walled Struct., vol. 145, no. May, p. 106376, 2019.

[10] Q. Gao, L. Wang, Y. Wang, and C. Wang. Crushing analysis and multiobjective crashworthiness optimization of foam-filled ellipse tubes under oblique impact loading, Thin-Walled Struct., vol. 100, pp. 105-112, 2016.

[11] J. Zhou, Q. Ruixian, and C. Bingzhi. Energy absorption properties of multi-cell thin-walled tubes with a double surface gradient, Thin-Walled Structures, vol. 145, pp. 106386, 2019.

[12] Y. Luo and H. Fan, Energy absorbing ability of rectangular self-similar multi-cell sandwichwalled tubular structures, Thin Walled Struct., vol. 124, no. March 2017, pp. 88-97, 2018.

[13] Y. Zhang, N. He, X. Song, T. Chen, and H. Chen, On impacting mechanical behaviors of side fractal structures, Thin-Walled Struct., vol. 146, no. October 2019, p. 106490, 2020.

[14] M. Abada and A. Ibrahim, Hybrid multi-cell thin-walled tubes for energy absorption applications : Blast shielding and crashworthiness, Compos. Part B, vol. 183, no. October 2019, p. 107720, 2020.

[15] E. Cetin and C. Baykaso, Energy absorption of thin-walled tubes enhanced by lattice structures, International Journal of Mechanical Sciences, vol. 158, no. April, pp. 471-484, 2019.

[16] G. Zhu, G. Sun, H. Yu, S. Li, and Q. Li, Energy absorption of metal , composite and metal / composite hybrid structures under oblique crushing loading, International Journal of Mechanical Sciences vol. 135, no. September 2017, pp. 458-483, 2018.

[17] A. E. Ismail, Energy Absorption Performances of Square Winding Kenaf Fiber Reinforced Composite Tubes, Int. J. Eng. Technol., vol. 6, no. 6, pp. 2662-2668, 2015.

[18] S. N. A. Khalid, A. E. Ismail, and M. H. Zainulabidin, A Review on Effect of Orientation Fabric on Mechanical Energy Absorption Natural Fibres Reinforced Composites, Appl. Mech. Mater., vol. 773-774, no. July, pp. 134-138, 2015.

[19] N. N. Hussain, S. P. Regalla, and Y. V. D. Rao, Low velocity Impact Characterization of Glass Fiber Reinforced Plastics for Application of Crash Box, Mater. Today Proc., vol. 4, no. 2, pp. 3252-3262, 2017.

[20] L. W. Ying, F. P. Yang, and X. Wang, Analytical method for the axial crushing force of fiber-reinforced tapered square metal tubes, Compos. Struct., vol. 153, pp. 222-233, 2016.

[21] K. Vinayagar and A. S. Kumar, Crashworthiness analysis of double section bi-tubular thin-walled structures, Thin-Walled Struct., vol. 112, no. June 2016, pp. 184-193, 2017.

[22] A. G. Jahromi and H. Hatami, Energy absorption performance on multilayer expanded metal tubes under axial impact, Thin-Walled Struct., vol. 116, no. March, pp. 1-11, 2017.

[23] Z. Wang, J. Liu, and S. Yao, On folding mechanics of multi-cell thin-walled square tubes, Compos. Part B, vol. 132, pp. 17-27, 2018.

[24] A. Baroutaji, M. D. Gilchrist, D. Smyth, and A. G. Olabi. Crush analysis and multi-objective optimization design for circular tube under quasi-static lateral loading, Thin-Walled Struct., vol. 86, pp. 121-131, 2015.

[25] A. A. Nia and S. Chahardoli. Optimizing the layout of nested three-tube structures in quasi-static axial collapse, Thin-Walled Struct., vol. 107, pp. 169-181, 2016.

[26] S. Chen, H. Yu, and J. Fang, A novel multi-cell tubal structure with circular corners for crashworthiness, Thin-Walled Struct., vol. 122, pp. 329-343, 2018.

[27] M. Altin, M. Güler, S. M.-I. J. of M. Sciences, and undefined 2017, The effect of percent foam fill ratio on the energy absorption capacity of axially compressed thin-walled multi-cell square and circular tubes, International Journal of Mechanical Sciences, vol. 131-132, pp. 368-379, 2017.

[28] T. Umeda and K. Mimura, Energy Absorption Due to Oblique Impact Crushing of Thin-Walled Tubes, in EPJ Web of Conferences, 2018, vol. 183, p. 4001.

[29] M. A. Gaikwad and M. K. Ukey, Experimental, Analytical and Numerical Study of Energy 
Absorption Properties of Aluminium Crush Boxes with and without Buckling Initiators (axial loading), Journal of Automobile Engineering and Applications, vol. 4, no. 2, pp. 35-42, 2017.

[30] J. Fu, Q. Liu, K. Liufu, Y. Deng, J. Fang, and Q. Li, Design of bionic-bamboo thin-walled structures for energy absorption, Thin Walled Struct., vol. 135, no. September 2018.

[31] S. Ming, C. Zhou, T. Li, Z. Song, and B. Wang, Energy absorption of thin-walled square tubes designed by kirigami approach, Int. J. Mech. Sci., vol. 157-158, no. 2, pp. 150-164, 2019.

[32] B. Jiang et al., Numerical, theoretical, and experimental studies on the energy absorption of the thin-walled structures with bio-inspired constituent element, Int. J. Mech. Sci., vol. 164, no. August, p. 105173, 2019.

[33] J. Ma and Z. You, Energy absorption of thin-walled square tubes with a prefolded origami pattern-part I: geometry and numerical simulation, J. Appl. Mech., vol. 81, no. 1, p. 11003, 2014.

[34] N. S. Ha, G. Lu, and X. Xiang, High energy absorption efficiency of thin-walled conical corrugation tubes mimicking coconut tree configuration, Int. J. Mech. Sci., vol. 148, no. September, pp. 409-421, 2018.

[35] S. Wang, Y. Peng, T. Wang, X. Chen, L. Hou, and H. Zhang. The origami inspired optimization design to improve the crashworthiness of a multi-cell thin-walled structure for high speed train, Int. J. Mech. Sci., vol. 159, no. May, pp. 345-358, 2019.

[36] S. Karimunnisa, V.S Kompalli. Cloud computing: Review on recent research progress and issue. International Journal of Advanced Trends in Computer Science and Engineering, Vol. 8, No. 2, pp. 216-223.

[37] A.D.M Africa, L.R. Bulda, M.Z. Marasigan, I.F. Navarro. A study on number gesture recognition using neural network. International Journal of Advanced Trends in Computer Science and Engineering, Vol. 8, No. 4, pp. 1076-1082.

[38] M.A. Arasi, S. Babu. Survey of machine learning techniques in medical imaging. International Journal of Advanced Trends in Computer Science and Enigneering, Vol. 8, No. 5, pp. 2107-2116. 